\title{
Are Menstrual Problems Associated with the Mental Health? A Cross Sectional Study among the Graduation College Girls
}

\author{
Quraishi SR, Waghachavare VB, Gore AD, Dhumale GB \\ Department of Community Medicine, Bharati Vidyapeeth Deemed University Medical College \& Hospital, Sangli \\ (Maharashtra) India - 416414.
}

\begin{abstract}
Introduction: Menstrual problems like menorrhagia, dysmenorrhea and premenstrual syndrome (PMS) are common in adolescent girls. However literature regarding association between menstrual and mental health problems is limited; hence the current study was planned. Methods: It is a cross-sectional study conducted in Sangli district (Maharashtra), India among the female students from three randomly selected graduation colleges. Calculated sample size was 605 and cluster random sampling technique was applied. The study duration was June 2013 - May 2014. Study instrument was self-administered questionnaire with inventories like PSST-A, DASS-21 and SPIN. Statistical analysis was done using chi-square test and binary logistic regression. Results: Of the 707 participants; 413 (58.4\%) had menstrual problems with dysmenorrhoea being the commonest. Embarrassment due to menstruation was felt by $14.9 \%$. Menstrual problems were associated with perceived body type, body image, stress and anxiety. Embarrassment due to menstruation was associated with social phobia, stress, anxiety and depression. On binary logistic regression; body image and embarrassment due to menstruation were significant predictors for menstrual problems. Conclusions: Menstrual problems contribute to the development of various Mental Health disturbances. Hence, girls should be encouraged to seek health advice for the menstrual problems. A full time Health counsellor in schools and colleges can justify addressing adolescent health problems.
\end{abstract}

KEYWORDS: Adolescent; menstruation disorders; mental disorder; India.

\section{INTRODUCTION}

Menstrual problems are common among the adolescent girls. On reviewing various studies regarding the menstrual problems; Greydanus and McAnamey (1982) concluded that dysmenorrhea, dysfunctional uterine bleeding, and amenorrhea are the three most common menstrual disorders among adolescents. ${ }^{1}$ DuflosCohade and Thibaud (2000) observed that long cycles and excessive uterine bleeding are the most common menstrual disorders in adolescents. ${ }^{2}$ Among the reviews done in the last decade, Slap GB (2003) stated that, Problems associated with menstruation affect $75 \%$ of adolescent females and are a leading reason for visits to physicians among which commonest are amenorrhoea, dysmenorrhoea and abnormal uterine

Corresponding author:

Dr. Vivek B. Waghachavare, Shivam Apt., Opp to Market Yard, Near Hotel Shivechha, Sangli-Miraj Road, Sangli (Maharashtra), India. Pin - 416416. Email : vivek416416@gmail.com

Phone : (+91)9503780277 bleeding. ${ }^{3}$ While McEvoy et al (2004), observed that menstrual disorders such as amenorrhea, excessive uterine bleeding, dysmenorrhea, and premenstrual syndrome are common reasons for visits to healthcare providers by adolescent girls. ${ }^{4}$ Considering the Indian scenario, Mashankar (2006) observed that some of the most common menstrual problems in adolescents are dysmenorrhoea, premenstrual syndrome, abnormal uterine bleeding, amenorrhoea and polycystic ovarian syndrome. ${ }^{5}$ Agarwal AK and Agarwal A (2010) observed that in Gwalior district, prevalence of dysmenorrhea in adolescent girls is $79.67 \% .^{6}$ Depressive disorder is most prevalent and higher among females. At specific stages of menstrual cycle, worsening of mental health is common. ${ }^{7,8}$ Barron ML et. al., observed a significant association between menstrual regularity and length of menstrual cycle with likelihood of developing psychiatric disorders. ${ }^{9}$

However, the literature regarding the association between menstrual and mental health problems is limited and majority of it is based in developed countries. Hence the current study was planned to find the extent of menstrual problems among adolescent girls from Sangli district (Maharashtra), India; and to study the association of these problems with certain mental health problems. 


\section{MATERIALS AND METHODS}

This is a cross-sectional study conducted in Sangli district from Maharashtra, India. Institutional ethical committee approval, permissions from the respective authorities and consents from participants were acquired. Study population was from female participants attending graduation course in the field of arts, commerce and science. Based on the prevalence from the similar previous study from India, sample size derived was 605. ${ }^{10}$ Sampling technique was cluster random sampling. The data was collected from three randomly selected graduation colleges. The admission to these graduation colleges is after passing higher secondary schools (i.e. 10+2 years of school education). Hence most of the students are of age group between 17 to 20 years. All the female students from selected colleges were invited to participate in the study. The inclusion criterion for the study participation was voluntary consent. In case of minors the voluntary consent has to be taken from parents/ guardians, hence only adult students i.e. those who were 18 years and above were included in the study. The students who was absent at the time of the data collection were excluded from the study. The study duration was from June 2013 - May 2014.

Study instrument was a pretested, self-administered questionnaire. The questionnaire was developed in English language. Initial section of the questionnaire had questions regarding socio-demographic factors, menstrual problems, symptoms of genitourinary infections experienced and other information were included in the instruments. The socioeconomic classification used was the Modified B. G. Prasad's classification. ${ }^{11}$ Similarly, various important menstrual problems were considered it the study. Dysmenorrhoea is defined as painful menstruation and menorrhagia as excessive or prolonged menstrual bleeding. Oligomenorrhoea means abnormally infrequent menstruation. While irregular menstruationis defined as abnormal frequency of menstrual bleeding i.e. cycles of more than 40 days or less than 20 days. While premenstrual syndrome (PMS) is the group of symptoms like irritability, insomnia, fatigue, headache and abdominal pain; manifested by some women prior to menstruation. ${ }^{12,13}$

The second section of the questionnaire had inventories for identifying various problems. Premenstrual syndrome screening tool for adolescents (PSST-A); a questionnaire developed and validated by Steiner et al., was used for identifying premenstrual syndrome. ${ }^{14}$ Stress, anxiety and depression are identified by "DASS-21" for which Lovibond had observed cronbach's alpha 0.76, and the internal consistency $0.83 .{ }^{15}$ Social phobia inventory (SPIN) is a validated 17 -itemed scale for social phobia.
Connor et al., reported; good test-retest reliability (Spearman correlation coefficient, $r=.78$ ), internal consistency (Cronbach's a, $r=0.56-0.76$ ) and convergent validity (comparing with the BSPS ratings; $r=$ 0.57-0.66) for SPIN. ${ }^{16}$ A six item scale was used for identifying body image; this was developed with the help of published literature and experts in the field and finalized after pilot study. ${ }^{17,18}$ It has good internal consistency;Cronbach's alpha 0.705 and split half validity coefficient 0.8 .

\section{Statistics}

Statistical analysis was done using percentage, chi-square test and binary logistic regression. Data from the pilot study and incomplete questionnaires were not included in the final analysis.

\section{RESULTS}

Out of 742 questionnaires, 707 were duly completed and hence included in final analysis. Majority of participants i.e. 529 (74.8\%) were 18 years old and the remaining were 19 years old. Among them 248 (35.1\%) belonged to rural area and $459(64.9 \%)$ to urban area. Regarding the graduation course of the participants; $161(22.8 \%)$ were arts, 338 (47.8\%) commerce and 208 (29.4\%) science students. Out of the total participants, 506 (71.6\%) belonged to nuclear family and remaining to the joint family. Regarding education of the mother as reported by participants; $61(8.6 \%)$ were illiterate, 475 (67.2\%) had primary or secondary school education and $171(24.2 \%)$ had college educated mother. Majority of participant i.e. 612 (86.6\%) had homemaker (housewife) mother, while remaining participants had working mother. Regarding Prasad's socioeconomic classification of the participants; 276 (39\%) belonged to class-I; 177 (25\%) to class-II, 102 (14.4\%) to class-III, $89(12.6 \%)$ to class-IV and $63(8.9 \%)$ to class V.

Participants had attended menarche from 10 to 16 yrs of age; with mean age of menarche was 14.5 years (standard deviation \pm 1.3 yrs) and mode was 15 years. Majority of participants, 413 (58.4\%) had one or more menstrual problems. Dysmenorrhoea was reported by 332 (47\%) participants; was the commonest menstrual problem. It was followed by perceived weakness during menstruation, menorrhagia, oligomenorrhoea / irregular menstruation and premenstrual syndrome. (Figure I)

For menstrual problems, 250 (35.4\%) participants had consulted doctor. One hundred five (14.9\%) felt that menstruation was embarrassing. Regarding menstruation and menstrual problems most of the participants had discussed with their mother 585 (82.7\%), friends $149(21.1 \%)$, while 47 (6.6\%) had not discussed with anybody. 


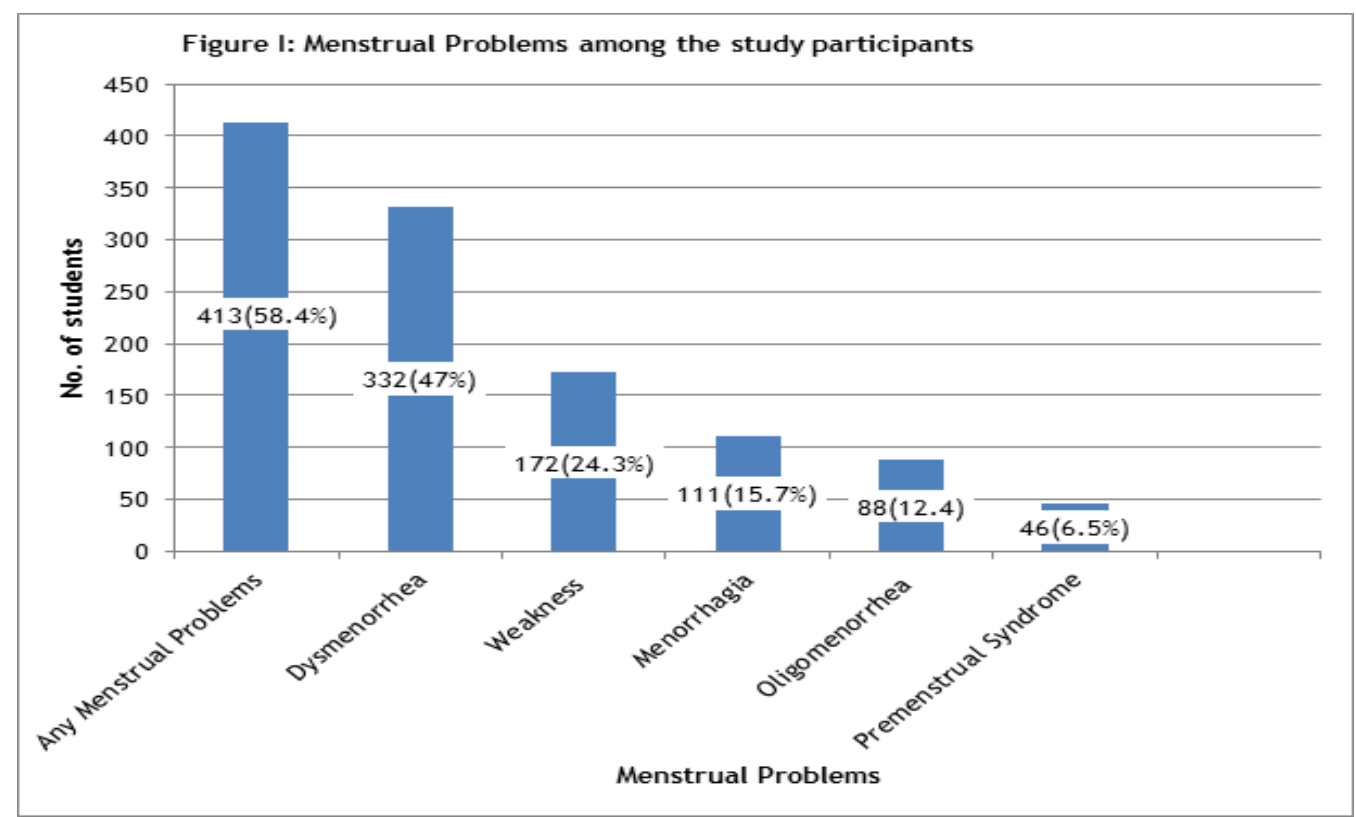

Mental Health problems present in participants were social phobia $203(28.7 \%)$, stress 179 (25.3\%), anxiety 291 (41.2\%) and depression 223 (31.5\%). Selfperceived underweight and overweight participants were $50(7.07 \%)$ each. Negative body image was present in $203(28.7 \%)$ study participants. Symptoms of genito-urinary tract infections were reported by 42 (5.9\%) participants. Majority of girls were in favour of addition of reproductive health education 474 (67\%), mental health education $652(92.2 \%)$ in the curriculum as well as provision of health cell in the college 685 (96.9\%).

Table I: Association of menstrual problems with various socio-demographic variables

\begin{tabular}{|c|c|c|c|c|c|}
\hline \multirow{2}{*}{\multicolumn{2}{|c|}{ Socio-demographic variables }} & \multicolumn{2}{|c|}{ Menstrual Problems } & \multirow{2}{*}{$\begin{array}{l}\text { Total } \\
(\mathrm{n}=707)\end{array}$} & \multirow{2}{*}{$\mathrm{p}$-value } \\
\hline & & \multirow{3}{*}{$\begin{array}{l}\begin{array}{l}\text { Absent } \\
(\mathrm{n}=294)\end{array} \\
242(45.7 \%) \\
52(29.2 \%)\end{array}$} & \multirow{2}{*}{$\begin{array}{l}\begin{array}{l}\text { Present } \\
(\mathrm{n}=413)\end{array} \\
287(54.3 \%)\end{array}$} & & \\
\hline Age & 18 & & & $529(100 \%)$ & 0.000 \\
\hline & 19 & & $126(70.8 \%)$ & $178(100 \%)$ & \\
\hline \multirow[t]{4}{*}{ Residence } & Rural & 119 (48\%) & 129 (52\%) & $248(100 \%)$ & 0.011 \\
\hline & Urban & $175(38.1 \%)$ & $284(61.9 \%)$ & 459 (100\%) & \\
\hline & 1 & $100(36.2 \%)$ & $176(63.8 \%)$ & $276(100 \%)$ & \\
\hline & II & 78 (44.1\%) & 99 (55.9\%) & 177 (100\%) & \\
\hline \multirow{4}{*}{$\begin{array}{l}\text { Prasad's Socioeconomic } \\
\text { class }\end{array}$} & III & $53(52 \%)$ & 49 (48\%) & $102(100 \%)$ & 0.042 \\
\hline & IV & $33(37.1 \%)$ & $56(62.9 \%)$ & $89(100 \%)$ & \\
\hline & V & $30(47.6 \%)$ & 33 (52.4\%) & 63 (100\%) & \\
\hline & Arts & $45(28 \%)$ & $116(72 \%)$ & $161(100 \%)$ & \\
\hline \multirow[t]{2}{*}{ Graduation course } & Commerce & $140(41.4 \%)$ & 198 (58.6\%) & $338(100 \%)$ & 0.000 \\
\hline & Science & $109(52 \%)$ & $99(48 \%)$ & $208(100 \%)$ & \\
\hline \multirow[t]{2}{*}{ Family Type } & Nuclear & $207(40.9 \%)$ & $299(59.1 \%)$ & $506(100 \%)$ & 0.563 \\
\hline & Joint & $87(43.3 \%)$ & $114(56.7 \%)$ & $20(100 \%)$ & \\
\hline \multirow[t]{3}{*}{ Mother Education } & Illiterate & 30 (49.2\%) & 31 (50.8\%) & $61(100 \%)$ & 0.394 \\
\hline & Attended School & 197 (41.5\%) & 278 (58.5\%) & $475(100 \%)$ & \\
\hline & Attended College & $67(39.2 \%)$ & $104(60.8 \%)$ & $171(100 \%)$ & \\
\hline \multirow[t]{2}{*}{ Mother Occupation } & Homemaker & $254(41.5 \%)$ & $358(58.5 \%)$ & $612(100 \%)$ & 0.911 \\
\hline & Other & $40(42.1 \%)$ & $55(57.9 \%)$ & 95 (100\%) & \\
\hline \multicolumn{2}{|l|}{ Total } & $294(41.6 \%)$ & 413 (58.4\%) & 707 (100\%) & \\
\hline
\end{tabular}


Age, residence, socio-economic class and graduation course were statistically associated with menstrual problems. These problems were higher among the participants of age 19 years and residing in urban area. On referring to socioeconomic classification, the menstrual problems were highest in those belonging to class-I. There was decreasing trend from class I to class II, however problems were higher again for participants belonging to class IV. Considering graduation course, menstrual problems were highest in participants pursuing arts, followed by commerce and lowest in science. However menstrual problems were not associated with family type, mother's education and mother occupation. Age of menarche was not associated with menstrual problems. (Table I) Menstrual problems were statistically associated with perceived body type; participants who considered themselves underweight had higher menstrual problems followed by those considered overweight. Menstrual problems were associated with negative body image, stress and anxiety; however not associated with depression and social phobia. (Table II)

Table II: Association of menstrual problems with various Mental Health problems

\begin{tabular}{|c|c|c|c|c|c|}
\hline \multirow{2}{*}{ Mental Health problems } & \multicolumn{3}{|c|}{ Menstrual Problems } & \multirow{2}{*}{$\begin{array}{l}\text { Total } \\
(n=707)\end{array}$} & \multirow[t]{2}{*}{$\mathrm{p}$-value } \\
\hline & \multicolumn{2}{|c|}{ Absent $(n=294)$} & Present & & \\
\hline & Underweight & $9(18.0 \%)$ & $41(82.0 \%)$ & $50(100 \%)$ & \\
\hline \multirow[t]{2}{*}{ Perceived body type } & Normal & $270(44.5 \%)$ & 337 (55.5\%) & 607 (100\%) & 0.000 \\
\hline & Overweight & $15(30 \%)$ & $35(70 \%)$ & 50 (100\%) & \\
\hline \multirow[t]{2}{*}{ Body image } & Positive & $276(44.1 \%)$ & $350(55.9 \%)$ & $626(100 \%)$ & 0.000 \\
\hline & Negative & $18(22.2 \%)$ & $63(77.8 \%)$ & 81 (100\%) & \\
\hline \multirow[t]{2}{*}{ Stress } & Absent & $246(46.6 \%)$ & $282(53.4 \%)$ & $528(100 \%)$ & 0.000 \\
\hline & Present & $48(26.8 \%)$ & $131(73.2 \%)$ & 179 (100\%) & \\
\hline \multirow[t]{2}{*}{ Anxiety } & Absent & 186 (44.7\%) & $230(55.3 \%)$ & $416(100 \%)$ & 0.044 \\
\hline & Present & $108(37.1 \%)$ & $183(62.9 \%)$ & $291(100 \%)$ & \\
\hline \multirow[t]{2}{*}{ Depression } & Absent & $212(43.8 \%)$ & $272(56.2 \%)$ & $484(100 \%)$ & 0.078 \\
\hline & Present & $82(36.8 \%)$ & 141 (63.2\%) & $223(100 \%)$ & \\
\hline \multirow[t]{2}{*}{ Social phobia } & Absent & 215 (42.7\%) & 289 (57.3\%) & $504(100 \%)$ & 0.361 \\
\hline & Present & 79 (38.9\%) & 124 (61.1\%) & $203(100 \%)$ & \\
\hline Total & & 294 (41.6\%) & $413(58.4 \%)$ & 707 (100\%) & \\
\hline
\end{tabular}

The menstrual problems were present in 34 (81\%) participants who had experienced symptoms of genitor-urinary tract infections and in 379 (57\%) participants who had not experienced such symptoms. The presence of symptoms of genito-urinary tract infections was statistically associated with menstrual problems (Chi-square $=9.336, p=0.002$ ) . The association between menstrual problems and embarrassment due to menstruation was statistically significant (Chi-square $=23.65, p=0.000)$. Participants suffering with menstrual problems were prone to develop embarrassment. The embarrassment due to menstruation was statistically associated with social phobia, stress, anxiety and depression. (Table III) 
Table III: Association of embarrassment due to menstruation with stress, anxiety, depression and social phobia.

\begin{tabular}{llllll}
\hline \multirow{2}{*}{ Mental Health problems } & \multicolumn{2}{c}{ Embarrassed due to menstruation } & Total & p-value \\
& & No $(\mathrm{n}=602)$ & Yes $(\mathrm{n}=105)$ & $(\mathrm{n}=707)$ & \\
\hline Social Phobia & Absent & $450(89.3 \%)$ & $54(10.7 \%)$ & $504(100 \%)$ & 0.000 \\
& Present & $152(74.9 \%)$ & $51(25.1 \%)$ & $203(100 \%)$ & \\
Stress & Absent & $459(86.9 \%)$ & $69(13.1 \%)$ & $528(100 \%)$ & 0.022 \\
& Present & $143(79.9 \%)$ & $36(20.1 \%)$ & $179(100 \%)$ & \\
Anxiety & Absent & $366(88 \%)$ & $50(12 \%)$ & $416(100 \%)$ & 0.011 \\
& Present & $236(81.1 \%)$ & $55(18.9 \%)$ & $291(100 \%)$ & \\
Depression & Absent & $422(87.2 \%)$ & $62(12.8 \%)$ & $484(100 \%)$ & 0.025 \\
& Present & $180(80.7 \%)$ & $43(19.3 \%)$ & $223(100 \%)$ & \\
\hline Total & & $602(85.1 \%)$ & $105(14.9 \%)$ & $707(100 \%)$ & \\
\hline
\end{tabular}

Binary logistic regression was applied, with predictors. Chance accuracy rate for the model is menstrual problems as dependent variable, while age, 75.4\%, which is greater than calculated chance accugraduation course, residence, prasad's socioeconomic racy rate $(67.3 \%)$. Body image and embarrassment due class, perceived body type, body image, stress, to menstruation were the highly significant predictors anxiety, depression, embarrassment due to for presence of menstrual problems. Stress, graduation menstruation and symptoms of genito-urinary tract course and socioeconomic class were also significant infections as independent variables. Wald's back- predictors. (Table IV)

ward method was used to identify most significant

Table IV: Binary regression model for association of menstrual problems with various variables

\begin{tabular}{|c|c|c|c|c|c|c|}
\hline Variables & B & S.E. & Wald & $\mathrm{df}$ & Sig. & OR (95\% C.I.) \\
\hline Age & 0.578 & 0.215 & 7.208 & 1 & 0.007 & $1.783(1.169,2.719)$ \\
\hline $\begin{array}{l}\text { Graduation } \\
\text { course }\end{array}$ & -0.431 & 0.129 & 11.178 & 1 & 0.001 & $0.650(0.505,0.837)$ \\
\hline $\begin{array}{l}\text { Prasad's } \\
\text { Socioeconomic } \\
\text { classification }\end{array}$ & -0.171 & 0.068 & 6.401 & 1 & 0.011 & $0.843(0.738,0.962)$ \\
\hline Body Image & 1.159 & 0.33 & 12.361 & 1 & 0.000 & $3.188(1.670,6.085)$ \\
\hline Stress & 0.682 & 0.212 & 10.41 & 1 & 0.001 & $1.979(1.307,2.995)$ \\
\hline $\begin{array}{l}\text { Embarrassed } \\
\text { due to } \\
\text { menstruation }\end{array}$ & 1.432 & 0.315 & 20.651 & 1 & 0.000 & $4.188(2.258,7.767)$ \\
\hline $\begin{array}{l}\text { Symptoms of } \\
\text { genito-urinary } \\
\text { tract infection }\end{array}$ & 0.805 & 0.461 & 3.05 & 1 & 0.081 & $2.237(0.906,5.522)$ \\
\hline Constant & -10.433 & 4 & 6.802 & 1 & 0.009 & 0 \\
\hline
\end{tabular}

$\mathrm{B}=$ Coefficient of regression, $\mathrm{SE}=$ Standard error, wald=Wald statistic, $\mathrm{df}=$ =degrees of freedom, Sig.= Significance, $\mathrm{OR}=$ Odds ratio, $\mathrm{Cl}=$ Confidence Interval. 


\section{DISCUSSION}

Current study showed mean age of menarche $14.5 \mathrm{yrs}$. More than $82 \%$ participants had discussed menstrual problem with mother and 35\% had consulted doctor. Nearly $15 \%$ participants were embarrassed due to menstruation. Higher percentages of participants have stress, anxiety, depression or social phobia had embarrassment due to menstruation. Menstrual problems were present in $58.4 \%$ participants, with dysmenorrhoea being the most common complaint. The menstrual problems were higher in participants residing in urban area, belonging to socioeconomic class-I and pursuing graduation in arts. Menstrual problems were higher equally in underweight as well as overweight participants. Similarly, participants having negative body image, stress, anxiety and experienced symptoms of genito-urinary tract infections had higher menstrual problems. A study in Delhi by Singh A et.al (2008) observed that the mean age of menarche was 12.5 years. ${ }^{19}$ Zegeye DT et.al. (2009) found that mean age of menarche among Ethiopian adolescents was 14.8 years. Similarly, they also concluded that the age of menarche of the inhabitants of rural area higher than their urban counterparts. $^{20}$ Verma et al. (2011) conducted similar study in Bhavnagar and observed that mean age of menarche was $14 .{ }^{21}$

Current study show mean age of menarche 14.5 yrs with equally between rural and urban areas. This observed mean age of menarche in the current study was similar to that observed by Vermaet $\mathrm{al}^{21}$ and Zegeye et al. ${ }^{20}$ However it was greater than observed by Singh A et. al in the India's capital city, New Delhi. ${ }^{19}$ This difference can be attributed to geographical variation from metropolitan city to smaller urban and rural area. Similar difference was observed by Motlagh ME et. al in Iran and Wronka et. al in Poland. ${ }^{22,23}$

Slap observed that problems associated with menstruation affect $75 \%$ of adolescent females. ${ }^{3}$ Thakre et al. observed menstrual problems among $71.8 \%$ adolescent girls. ${ }^{10}$ However in present study menstrual problems were observed among $58.4 \%$ girls. The difference is attributed to different attitude and geographical variations.

Singh A et.al in their study observed that $73.83 \%$ subjects complained dysmenorrhoea. ${ }^{19}$ While observed dysmenorrhoea in the study by Zegeye DT et.al and Sharma $P$ et.al was $72 \%$ and $67.2 \%$ respectively. ${ }^{20,24}$ In the current study, even though it was the most common complaint; yet it was reported by only $42.5 \%$ subjects. This is much lower than what is observed in above mentioned studies. However the results are much closer to observed result of $50.6 \%$ dysmenorrhoea among girls from Bhavnagar, by Vermaet et al. ${ }^{21}$ The dysmenorrhoea and its severity are perceptive. Similarly it depends on personal threshold for pain; social environment in one is brought up. This may be the reason for observed differences in the results.

Thakre et al, observed a significant difference in proportion of menstrual problems in rural and urban girls. ${ }^{10}$ They observed that significantly larger percentage of urban girls reported dysmenorrhoea and symptoms of PMS. Avasarala AK and Panchangam S observed that girls in the urban area take dysmenorrhoea more seriously and often resort to treatment as compared to those from rural area. ${ }^{25}$ In the current study, it was observed that menstrual problems were reported more by girls from urban areas as compared to their counterparts from rural areas. Thus the results obtained are consistent with the findings of other researchers. ${ }^{10,25}$

We observed that menstrual problems were associated with perceived body type. In a study conducted in Hyderabad from Pakistan, Dars et.al. observed statistical association between BMI and menstrual patterns. ${ }^{26}$ Similar results were observed by Bassi et.al., in Amritsar. ${ }^{27}$

On studying menstrual problems in female medical students from Pondicherry, Lakkawar et al. observed that students with higher BMI had higher incidence of irregular menstruation. They also found significant association of psychological stress with menstrual disorders. ${ }^{28}$ In the current study we found that menstrual problems were associated with stress and anxiety. Similarly menstrual problems were common in participants with depression. Thus observations from our study are similar to that of Lakkawar et.al.

The majority of participants in our study favoured inclusion of education related to reproductive health and mental health, in the curriculum; as well as setting up of health cell in the college. It has been well documented in the literature that health education, promotion and school/college based interventions may help in reducing or managing menstrual problems and mental health issues..$^{29,30}$

\section{Limitations of the study}

Study population is college students hence the results cannot be applied to all the adolescent population. Similarly the study is cross-sectional hence the conclusions are only indicative. More such studies with greater reach and better study design are required for the better conclusions regarding the topic. Being a self-administered questionnaire, reporting bias cannot be totally eliminated; there may be overestimation of menstrual or mental health problems. Many confounding factors like various variables of family background, health status, academic performance, IQ and personality of the study participants etc., may affect the mental health but due to time and feasibility constraints these were not controlled. Confirmation was not sought for anymenstrual or mental health problem. 


\section{Recommendations}

Late adolescent girls suffer from one or more menstrual problems, commonest being dysmenorrhoea. They are associated with various Mental Health disturbances like stress, depression and anxiety. Urban lifestyle and malnutrition are additional associated factors of menstrual problems. Only one third of study group sought medical advice. "Embarrassment" regarding menstruation is a major hindrance in health seeking behaviour; it also associated with social phobia, anxiety and depression. Sound Scientific knowledge while addressing menstrual problems may help in better dealing with the situation. Generally girls discuss and seek advice from mother; involvement of their teachers is negligible.

It is strongly recommended to conduct separate lectures for girls since early adolescents, to impart them knowledge about menstruation and possible menstrual disorders. They should be encouraged to seek health advice regarding the same. Periodic parents meetings regarding handling the adolescents' health problems should be encouraged. Parents especially mothers should be educated to identify and tackle the adolescent health problems. All the teachers must undergo periodic training and retraining regarding adolescent health. Female teachers should be encouraged to have discussion with all the girls regarding menstrual problems. Similarly, they should have at least one session with each girl individually of their class, to discuss about any problem or misconception regarding adolescent health issues specifically addressing menstrual problems. A health counsellor should be appointed in schools and colleges to address the adolescent health problems.

\section{CONCLUSION}

Late adolescent girls suffer from one or more menstrual problems, which are associated with various mental health disturbances like stress, depression and anxiety.

\section{Conflict of Interest}

None to declare.

\section{REFERENCES}

1. Greydanus DE, McAnarney ER. Menstruation and its disorders in adolescence. Curr Probl Pediatr 1982; 12:1-61.

2. Duflos-Cohade C, Thibaud E. [Menstrual cycle disorders in adolescents]. Archives de Pédiatrie [Internet], 2000 [Cited on 2015 May, 29];7: 767-72. [Article in French] Available from: http: //www.em-consulte.com/article/6774/alertePM.

3. Slap GB. Menstrual disorders in adolescence. Best Pract Res Clin Obstet Gynaecol 2003; 17: 75-92.

4. McEvoy M, Chang J, Coupey SM. Common menstrual disorders in adolescence: nursing interventions. MCN Am J Matern Child Nurs 2004; 29:41-9.

5. Mashankar VA. Menstrual Problems in adolesecnts. In: Bhave SY, editor. Bhave's Text book of Adolescent Medicine. New Delhi: Jaypee Brothers Medical Publishers (P) Ltd; 2006. p. 95-104.

6. Agarwal AK, Agarwal A. A study of dysmenorrhea during menstruation in adolescent girls. Indian J Community Med [serial online] 2010 [cited 2015 June 4];35: 159-64. Available from: http://www.ijcm.org.in/ text.asp?2010/35/1/159/62586.

7. Pinkerton JV, Guico-Pabia CJ, Taylor HS. Menstrual cycle-related exacerbation of disease. Am J Obstet Gynecol [Serial Online]. 2010 Cited on 2015, Aug 4];202:221-31. Available from: http://www.ncbi.nlm.nih.gov/pmc/ articles/PMC3107848/

8. Case AM, Reid RL. Menstrual cycle effects on common medical conditions. Compr Ther 2001; 27:65-71.

9. Barron ML, Flick LH, Cook CA, Homan SM, Campbell C. Associations between Psychiatric Disorders and Menstrual Cycle Characteristics. Arch Psychiatr Nurs [Serial Online]. 2008[Cited on 2015, Aug 4];22:254-65. Available on:

http: / /www.ncbi.nlm.nih.gov/pmc/articles/ PMC2588420/

10. Thakre SB, Thakre SS, Ughade SU, Thakre AD. Urban-Rural differences in Menstrual Problems and Practices of Girl students in Nagpur, India. Indian Pediatr 2012;49: 733-6.

11. Mangal A, Kumar V, Panesar S, Talwar R, Raut D, Singh S. Updated BG Prasad socioeconomic classification, 2014: A commentary. Indian J Public Health [serial online] 2015 [cited $2015 \mathrm{Jul}$ 21];59:42-4. Available from: http: / / www.ijph.in/ text.asp?2015/59/1/42/152859

12. Mashankar VA. Menstrual Problems in adolesecnts. In: Bhave SY, editor. Bhave's Textbook of Adolescent Medicine. New Delhi: Jaypee Brothers Medical Publishers (P) Ltd; 2006. p.95-104.

13. The National Center for Biotechnology Information. Glossary of term [Internet]. Bethesda MD: U.S. National Library of Medicine. 2015 [cited July 4, 2015]. Available from: http:// www.ncbi.nlm.nih.gov/mesh/.

14. Steiner M, Peer M, Palova E, Freeman EW, Macdougall M, Soares CN. The Premenstrual Symptoms Screening Tool revised for adolescents (PSST-A): prevalence of severe PMS and premenstrual dysphoric disorder in adolescents. Arch Womens Ment Health [Serial Online]. 2011 [Cited on April 10, 2015];14:77-81.

Available on: http:/ /www.springerlink.com/ content/q0833170puu1j503/.

15. Lovibond SH, Lovibond PF. Manual for the Depression Anxiety Stress Scales. 2nd Ed. Sydney: Psychology Foundation, 1995.

16. Connor KM, Davidson JR, Churchill LE, Sherwood A, Foa E, Weisler RH. Psychometric properties 
of the Social Phobia Inventory (SPIN). New self-rating scale. Br J Psychiatry 2000; 176: 379-86.

17. Nayar PD, Mehta R. Adolescent Body Image Perspectives, Impact and Management. In Bhave SY. Bhave's Textbook of Adolescent Medicine. New Delhi: Jaypee Brothers Medical Publishers (P) Ltd, 2006;166-72.

18. American Psychiatric Association. Diagnostic and statistical manual of mental disorders. 4th edn. Text rev. Washington, DC: American Psychiatric Association, 2000.

19. Singh A, Kiran D, Singh $H$, Nel B, Singh P, Tiwari P. Prevalence and severity of dysmenorrhea: a problem related to menstruation, among first and second year female medical students. Indian J Physiol Pharmacol 2008; 52:389-97.

20. Zegeye DT, Megabiaw B, Mulu A. Age at menarche and the menstrual pattern of secondary school adolescents in northwest Ethiopia. BMC Womens Health 2009; 9:29.

21. Verma PB, Pandya CM, Ramanuj VA, Singh MP. Menstrual Pattern of Adolescent School Girls of Bhavnagar (Gujarat). NJIRM 2011; 2:38-40.

22. Motlagh ME, Rabbani A, Kelishadi R, et al. Timing of puberty in Iranian girls according to their living area: a national study. J Res Med Sci 2011; 16:276-81.

23. Wronka I, Pawlińska-Chmara R. Menarcheal age and socio-economic factors in Poland. Ann Hum Biol 2005; 32:630-8.

24. Sharma P, Malhotra C, Taneja DK, Saha R. Problems related to menstruation amongst adolescent girls. Indian J Pediatr 2008; 75:125-9.

25. Avasarala AK, Panchangam S. Dysmenorrhoea in different settings: are the rural and urban adolescent girls perceiving and managing the dysmenorrhoea problem differently?. Indian J Community Med 2008; 33:246-9.

26. Dars S, Sayed K, Yousufzai Z. Relationship of menstrual irregularities to $\mathrm{BMI}$ and nutritional status in adolescent girls. Pak J Med Sci [Serial Online]. 2014 [cited on June 24, 2015];30: 141-4. Available from: http://www.ncbi.nlm. nih. gov/pmc/articles/PMC3955559/

27. Bassi R, Sharma S, Saini AS, Kaur M. Correlation of Menstrual Pattern with Body Mass Index in Young Female Students. J Phys Pharm Adv [Serial Online]. 2015[cited on June 24, 2015];5:556-64. Available from: http: //www.grjournals.com/portals/grjournals/ JPPA/Vol5\%20lssue2/JPPA-2015-556-564.pdf

28. Lakkawar NJ, Jayavani RL, Nivedhana AP, Alaganandam P, Vanajakshi N. A Study of Menstrual Disorders in Medical Students and its Correlation with Biological Variables. Sch J App Med Sci [Serial Online]. 2014 [cited on June 24, 2015];2(6E):3165-75. Available from: http:// saspublisher.com/wp-content/uploads/2014/11/ SJAMS-26E3165-3175.pdf

29. Solanki DH, Gosalia DV, Patel DH, Vora DF, Singh MP. A Study of Menstrual Problems \& Practices among Girls of Mahila College. NJIRM. (2012), [cited July 25, 2015];3:24-7. Available from: http: //www.scopemed.org/?mno=27535

30. Weare K, Nind M. Mental health promotion and problem prevention in schools: what does the evidence say? Health Promot Int 2011, [cited July 25, 2015];26Suppl 1:i29-69. Available from: http://heapro.oxfordjournals.org/content/26/ suppl_1/i29.long\#sec-33 